\title{
Evaluation of Shigella flexneri Biofilm Formation and Its Effect on the Expression of Toxin-antitoxin Genes
}

\author{
Erfan Kheradmand ${ }^{1}$, Shabnam Razavi ${ }^{2,3}$ * iD, Malihe Talebi ${ }^{2,3}$ (D), Mahmoud jamshidian ${ }^{4}$
}

1. Department of Biology, Science and Research Branch, Islamic Azad University, Tehran, Iran

2. Microbial Biotechnology Research Center, Iran University of Medical Sciences, Tehran, Iran

3. Department of Microbiology, School of Medicine, Iran University of Medical Sciences, Tehran, Iran

4. Department of Pathobiology, Science and Research Branch, Islamic Azad University, Tehran, Iran

10.30699/ijmm.15.5.538

\section{ABSTRACT}

Background and Aim: Shigella flexneri is a highly contagious Gram-negative bacterium that causes severe diarrhea, especially in children under ten years old. The biofilm formation in this species increases its resistance to antibiotics. Given the important role of toxin-antitoxin (TA) systems in the stability and survival of bacteria under stress condition, this study was aimed to evaluate the expression of genes encoding TA systems and Lon protease (lonp) as the main protein regulating the expression and function of these systems in this microorganism in terms of biofilm formation.

Materials and Methods: In this study, the standard Shigella f. ATCC 12022 was used. After the bacteria culture on the specific culture medium, the ability to form biofilm was quantitatively evaluated by microtiter plate method. Then, the expression level of the mentioned genes was assessed compared to the control group using real-time PCR.

Results: The results of microtiter plate test showed that the studied Shigella $f$. was a strong biofilm strain. The qPCR results showed an increase in gene expression of the studied toxins and Lon protease at 8 and $24 \mathrm{~h}$ following biofilm formation induction $(P<0.01)$

Conclusion: Due to the significant increase in the expression of the studied genes, especially Lon protease, GNAT and maz toxins at $24 \mathrm{~h}$ after biofilm formation, they can be potentially used as antimicrobial targets in new studies.

Keywords: Biofilm, Microtiter plate, Real-Time PCR, Shigella flexneri, Toxin-antitoxin

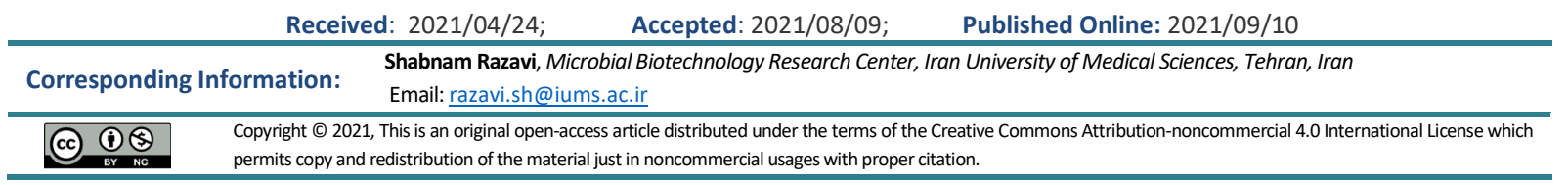

Use your device to scan and read the article online

Kheradmand E, Razavi S, Talebi M, Jamshidian M. Evaluation of Shigella flexneri Biofilm Formation and

Its Effect on the Expression of Toxin-antitoxin Genes. Iran J Med Microbiol. 2021; 15 (5):538-550

Download citation: BibTeX | RIS | EndNote | Medlars | ProCite | Reference Manager | RefWorks

Send citation to: $8 \underline{\text { Mendeley }} 2$ zotero $\underline{\dot{H}}$ RefWorks

\section{Introduction}

Shigella flexneri is a low-dose infectious microorganism that swallowing a small number of it (about 100 bacteria/ml) can cause infection. This is the main reason for the high prevalence of the disease, which is estimated for 165 million infected people and 1.1 million deaths worldwide per year $(1,2)$. Similar to other diarrheal diseases, shigellosis is treated with intravenous serum injection. Shigella infections respond to the antibiotic treatment by reducing fever and diarrhea, but there have been several reports of the antibiotic resistance (3). Therefore, to deal with the infectious agents resistant to antibiotics several studies must be conducted on pathogenicity, ways to escape the immune system, and resistance to antibiotics. In this study, the biofilm formation of Shigella $f$. and its association with the changes in the expression of TA (Toxin-Antitoxin) genes were investigated $(4,5)$.

Biofilms are aggregates of microbial colonies that form a cellular matrix containing a protective polysaccharide layer. The biofilm formation is the 
major factor involved in bacterial survival and resistance (6). In general, bacterial resistance in biofilm condition is much higher than planktonic state; one of the main reasons for this resistance is the polysaccharide matrix, which prevents the antibiotics penetration. In addition, lower level of bacterial metabolic activity in biofilm is another reason for the resistance to antibiotics (7).

Studies on Shigella $f$. have shown that prolonged exposure of the bacterium to the bile salts leads to biofilm formation (8). In addition, salt concentration can significantly affect the capacity of Shigella to produce biofilm in microplate wells (9). Ferulic acid has also been reported to limit the formation of biofilms by Shigella $f$. (10). These indicate the effect of different salts and acids on the biofilm formation of this bacterium.

On the other hand, in the case of TA systems, recent studies have shown that under stress condition, antitoxin is selectively degraded, which causes toxin activation and function $(11,12)$. It has been suggested that toxins in these systems are associated with various cellular processes such as regulating gene expression (13).

Several evidences have shown that these systems are involved in the formation of biofilm and Quorum sensing $(14,15)$. Lon protease is a protected and ATPdependent serine protease in bacteria that selectively degrades mutated and abnormal proteins as well as some short-lived regulatory proteins such as antitoxins. Thus, by releasing the toxin it is activated. This protease plays a pivotal role in different bacterial mechanisms, including cell differentiation, participation in biofilm production, and bacterial survival $(16,17)$.

Since there was not much information about the existence and prevalence of these systems in Shigella $f$., and due to the regular updating of the databases related to these systems, we evaluated the expression of these genes in the cell culture following cell infection by Shigella $f$. during a study after the identification of TA systems by these databases as well as the design of specific sequences of the related primers with the help of authentic software. This study was conducted in line with our previous study (18). The aim of this study was to investigate the changes in gene expression compared to the control by examining the biofilm of Shigella $f$..

\section{Materials and Methods}

\section{Bacterial Preparation and DNA Extraction}

This study was performed in 2019 in the laboratories of Iran University of Medical Sciences. The standard strain of Shigella $f$. (ATCC 12022) was prepared from the Microbial Bank of the Department of Microbiology,
Iran University of Medical Sciences. The bacteria was cultured on Hektoen enteric agar (HEK) (Merck, Germany) and incubated at $37^{\circ} \mathrm{C}$ for $24 \mathrm{hr}$. The boiling method was used to extract genomic DNA (19). The quality and concentration of the extracted DNA were evaluated by Nanodrop (Nanodrop Technologies, Wilmington, De, USA). After reading the adsorption ratio of 260/280 and ensuring the purity of DNA, the sample was stored in a sterile microtube at $-70^{\circ} \mathrm{C}$ for further use.

\section{Polymerase chain Reaction and Electrophoresis}

PCR was performed in a thermal cycler (Bio-Rad, USA) using Master Mix (Fermentas, Lithuania) (12.5 $\mu \mathrm{L})$ and extracted DNA $(1 \mu \mathrm{L})$. The specific forward and reverse primers were used at $10 \mathrm{pM}$ concentration (1 $\mu \mathrm{L} /$ each) (18). The final volume reached to $25 \mu \mathrm{L}$ using nuclease-free water. The cycling program was as follow: an initial denaturation step at $95^{\circ} \mathrm{C}$ for $5 \mathrm{~min}$, 35 cycles of denaturation at $95^{\circ} \mathrm{C}$ for $1 \mathrm{~min}$, annealing at $60^{\circ} \mathrm{C}$ for $1 \mathrm{~min}$, and extension at $72^{\circ} \mathrm{C}$ for $25 \mathrm{sec}$, and a final elongation phase at $72^{\circ} \mathrm{C}$ for $5 \mathrm{~min}$. The PCR products were electrophoresed on $2 \%$ agarose gel. For this purpose, $2 \mathrm{gr}$ of agarose powder (Sigma-Aldrich) was dissolved in $100 \mathrm{ml}$ of $0.5 \mathrm{X}$ TBE buffer. After gel preparation and adding DNA Safe Stain, it was transferred to the tank and the samples were loaded in the wells. Finally, the bands were examined and photographed using gel doc.

\section{Quantitative Evaluation of Biofilm Formation by Microtiter Plate Method}

Shigella $f$. was cultured in trypticase soy broth (TSB) medium containing $1 \%$ glucose for $24 \mathrm{~h}$ at $37^{\circ} \mathrm{C}$, and then a suspension equivalent to half McFarland was prepared. Then, $200 \mu \mathrm{L}$ was inoculated into the wells of 96-well microplate. After incubation for $24 \mathrm{~h}$ at $37^{\circ} \mathrm{C}$, the wells were washed three times with PBS to remove unabsorbed bacteria. The absorbed bacteria were then fixed for 15 min using 95\% ethanol and the plate was air dried. The wells were stained with $200 \mu \mathrm{L}$ of $0.02 \%$ crystal violet for $5 \mathrm{~min}$. The microplate was then washed twice with distilled water to remove the excess dye. After drying, $200 \mu \mathrm{L}$ of $33 \%$ glacial acetic acid was added. Following the contents fixation with ethanol, the adsorption of the dye dissolved in acetic acid was measured at $492 \mathrm{~nm}$ wavelength. The culture medium alone was used as negative control. Thus, to quantitatively evaluate the ability of Shigella $f$. to produce biofilm, the average adsorption of three wells was calculated and compared with the average adsorption of three control wells (uncultivated medium). The ability of bacteria to produce biofilm was determined. The ability to form biofilm was obtained through Table 1. To ensure the accuracy of the work, these tests and measurements were repeated thrice at different times (20). 
Table 1. Calculating the ability of biofilm formation compared to the control

\begin{tabular}{ll}
\multicolumn{1}{c}{ Degree of biofilm production } & \multicolumn{1}{c}{ Intensity of colorimetry } \\
Lack of production & $O D<O D_{n c}$ \\
Weak & $O D_{n c}<O D<2 \times O D_{n c}$ \\
Medium & $2 \times O D_{n c}<O D<4 \times O D_{n c}$ \\
Strong & $4 \times O D_{n c}<O D$ \\
\hline
\end{tabular}

\section{Investigation of Gene Expression in Biofilm using qPCR and Livak Method}

At 8 and $24 \mathrm{~h}$ after induction of biofilm formation in Shigella $f_{\text {., }}$ total RNA was extracted using RNA extraction kit (Roche, Germany). To measure the concentration and purity of RNA, the amount of optical density was read using nanodrop. After ensuring the purity of the extracted RNA, cDNA was synthesized using cDNA synthesis kit (GeneAll Biotechnology, South Korea). The 16S rRNA gene was used for the data normalization. Then, the expression of the studied genes was measured in the presence of internal control gene compared to the control sample. All experiments were performed thrice.

Each sample was done in duplicate. For each gene, two microtubes without template were placed to ensure the absence of contamination. To prepare the reaction mix with a total volume of $20 \mu \mathrm{L}, 5 \mu \mathrm{L}$ of sybr green Master Mix (qPCR Master Mix, Bioneer, Korea), $1 \mu \mathrm{L}$ of $\mathrm{cDNA}$, specific forward and reverse primers with $10 \mathrm{pM}$ concentration $(0.5 \mu \mathrm{L} /$ each) and $13 \mu \mathrm{L}$ nuclease-free water was used. All the steps were performed on ice. After spinning for $10 \mathrm{sec}$, samples were placed inside Rotor Gene thermal cycler (Corbett, Australia). The thermal cycling consisted of an initial activation step at $95^{\circ} \mathrm{C}$ for $10 \mathrm{~min}, 45$ cycle of denaturation at $95^{\circ} \mathrm{C}$ for $15 \mathrm{sec}$, annealing and extension at $60^{\circ} \mathrm{C}$ for $30 \mathrm{sec}$. Real-time PCR results were analyzed using Rest software and the amount of gene expression (fold change) was calculated using Livak method $(18,21)$.

\section{Statistical Analysis}

All data was presented based on three replications in each experiment and the mean of the measurements was performed in three replications and its statistical analysis was determined by analysis of variance (ANOVA) and P-value<0.01 using SPSS 22 (SPSS Inc., Chicago, III., USA).

\section{Results}

\section{Polymerase Chain Reaction Test Result}

The PCR results shown in Figure 1, confirmed the presence of TA systems genes (from left to right, toxin and then antitoxin, respectively), as well as Lon protease (lonp) in the studied Shigella $f$. strain.

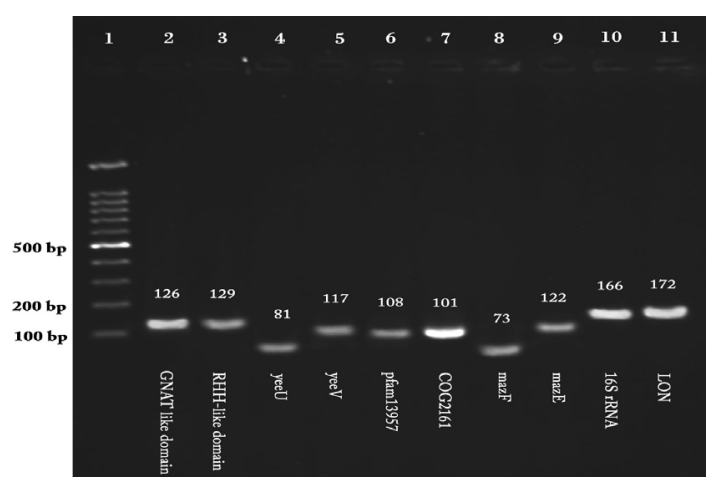

Figure 1. PCR results of the studied genes in Shigella flexneri strain

\section{Results of Shigella f. Biofilm Formation and Genes Expression}

The ability of the studied Shigella $f$. strain to produce biofilm was evaluated by microtiter plate method using ELISA reader. The results showed that the tested strain was able to produce biofilm strongly. The qPCR results showed a fold increase in the expression of TA systems and lon $P$ genes at 8 and $24 \mathrm{~h}$ after biofilm formation compared to the control. The results of the expression of the studied genes in the mentioned hours are shown in Figures 2 and 3, respectively $(P<0.01)$. 


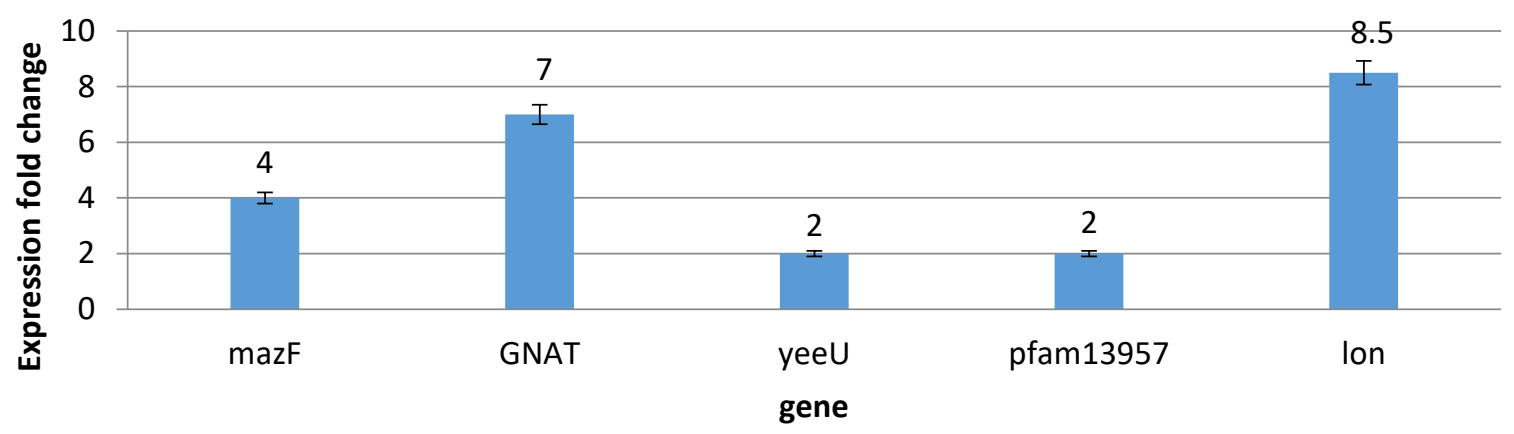

Figure 2. Results of expression of the studied genes in biofilm conditions compared to the control sample at 8 hour (results normalized in the presence of 16S rRNA internal control gene) $(P<0.01)$

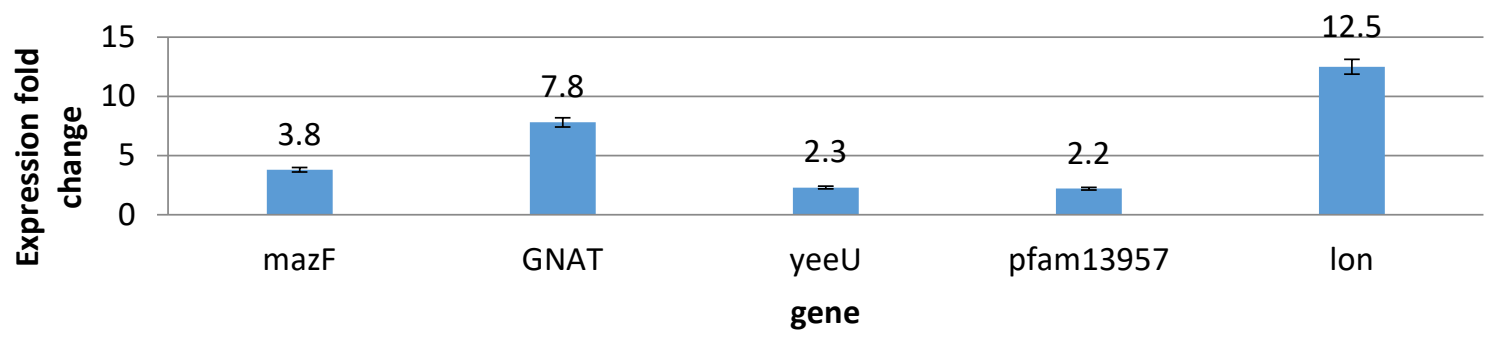

Figure 3. Results of expression of the studied genes in biofilm conditions compared to the control sample at 24 hour (results normalized in the presence of $16 \mathrm{~S}$ rRNA internal control gene) $(P<0.01)$

\section{Discussion}

According to the obtained results for the TA systems increased expression level in terms of biofilm formation, it is possible to understand the association between these systems and biofilm formation. Hemati et al., in 2014, using PCR method, showed that in the clinical isolates of Pseudomonas aeruginosa, which have a high ability to form biofilms, TA systems and Quorum sensing genes are abundant (22), which indicates the association of biofilm formation with the presence of TA systems. This is consistent with the results of our study. In a study in 2016, Wood et al., identified a type II TA system called HigB/HigA in Pseudomonas aeruginosa PA14 and showed that HigB toxin affects biofilm production and virulence factors, and thus this system affects the pathogenicity of this strain (23).

In 2017, Valadbeigi et al., investigated the effect of a compound called PNA on the expression of the mazE antitoxin gene and its effect on biofilm formation in 18 clinical isolates of Pseudomonas aeruginosa. They mentioned that mazE antitoxin gene could be targeted for controlling the biofilm production by Pseudomonas aeruginosa (24).

In 2018, Chan et al., identified four TA systems, including pezAT, yefM-yoeB, relBE, and phD-doc in Streptococcus pneumoniae. They showed that strains lacking the yefM-yoeB system, as well as mutants in both yefM-yoeB and relBE systems, had a significant reduction in biofilm formation ability (25). This indicates that, similar to our results, there is a significant association between the presence of some TA systems and biofilm formation.

In a study in 2019, Alhusseini et al., examined 54 isolates of Pseudomonas aeruginosa MDR and evaluated the presence of five type II TA systems, including relBE, hipBE, mazE, ccdAB, and mqsR. They observed biofilm formation in $90.74 \%$ of the isolates. Also, PCR results for identifying the gene loci of TA systems showed a very high percentage of these systems in the studied isolates (26). These results were similar to the present study outcome.

In a study by Ma et al., in 2019 conducted on 3 strains of Staphylococcus aureus, the role of the MazEF system in infections as well as the association between this system and increased biofilm growth was demonstrated (27).

Numerous results of other bacteria have shown that maz toxin helps bacteria survive in harsh conditions. This system was also present in our studied strain. In Myxococcus xanthus, a Gram-negative bacterium, MazF plays an important role. It is induced by the 
formation of a spore-producing body, resulting in the death of $80 \%$ of the cell population by cell lysis and the remaining $20 \%$ of the cells are capable of forming spore-producing bodies (28).

Kwan et al., in a study in 2015, examined the MqsR/MqsA type II system in Escherichia coli and showed that due to the high concentration of deoxycholate in the gallbladder and upper intestine, this system is physiologically important and vital for the growth and survival of Escherichia coli cells in these areas, which have a high concentration of bile salts (29).

Targeting the important toxins and their regulating protease is suggested as an appropriate method of treatment. One method to target a gene is antisense technology. Javanmard et al., in a study in 2020, designed and applied antisense against cagA gene in Helicobacter pylori and showed that antisense along with penetrating peptide could be used as an effective tool to inhibit the target gene mRNA (30).

\section{Conclusion}

In the present study, the expression of genes was evaluated in biofilm condition compared to the control with lack of biofilm formation. The results showed that GNAT and maz toxins genes expression had a significant increase in biofilm conditions

\section{References}

1. Baker S, The HC. Recent insights into Shigella: a major contributor to the global diarrhoeal disease burden. Curr Opin Infect Dis. 2018;31(5):449-54. [PMID] [PMCID] [DOI:10.1097/QCO.0000000000000475]

2. Schroeder NG, Hilbi H. Molecular Pathogenesis of Shigella spp.: Controlling Host Cell Signaling, Invasion, and Death by Type III Secretion. Clin Microbiol Rev. 2008;21(1):134-56. [DOI:10.1128/CMR.00032-07] [PMID] [PMCID]

3. Tajbakhsh $M$, García Migura $L$, Rahbar $M$, Svendsen CA, Mohammadzadeh M, Zali MR, et al. Antimicrobial-resistant Shigella infections from Iran: an overlooked problem? J Antimicrob Chemother. 2012;67(5):1128-33. [DOI:10.1093/jac/dks023] [PMID]

4. Xu D, Zhang W, Zhang B, Liao C, Shao Y. Characterization of a biofilm-forming Shigella flexneri phenotype due to deficiency in Hep biosynthesis. PeerJ. 2016;4:e2178. [DOI:10.7717/peeri.2178] [PMID] [PMCID] compared to the control group. These results suggest that these two systems may contribute to the formation of biofilms. In addition, due to the increased expression of Lon protease gene, its importance and necessity in bacterial survival can be realized through regulation and control of TA systems in biofilm conditions. Therefore, this protein can be a favorable target for introducing new therapeutic compounds.

\section{Acknowledgment}

We would like to express our gratitude to all the people who cooperated effectively during this study. It is worth mentioning that this article is the result of a part of Mr. Erfan Kheradmand's doctoral dissertation from the Islamic Azad University, Science and Research Branch.

\section{Funding}

This article is an independent study that was conducted without organizational financial support.

\section{Conflict of Interest}

The authors declared no conflict of interest.

5. Kang J, Liu L, Liu M, Wu X, Li J. Antibacterial activity of gallic acid against Shigella flexneri and its effect on biofilm formation by repressing mdoH gene expression. Food Control. 2018;94: 147-54. [DOI:10.1016/i.foodcont.2018.07.011]

6. Høiby N, Bjarnsholt T, Givskov M, Molin S, Ciofu O. Antibiotic resistance of bacterial biofilms. Int J Antimicrob Agents. 2010;35(4):322-32. [DOI:10.1016/j.ijantimicag.2009.12.011] [PMID]

7. Dadgar T, Vahedi Z, Yazdansetad S, Kiaei E, Asaadi $\mathrm{H}$. Phenotypic Investigation of Biofilm Formation and the Prevalence of icaA and icaD Genes in Staphylococcus epidermidis Isolates. Iran J Med Microbiol. 2019;12(6):371-81. [DOI:10.30699/ijmm.12.6.371]

8. Nickerson KP, Chanin RB, Sistrunk JR, Rasko DA, Fink PJ, Barry EM, et al. Analysis of Shigella flexneri Resistance, Biofilm Formation, and Transcriptional Profile in Response to Bile Salts. Infect Immun. 2017;85(6):e0106716. [DOI:10.1128/IAI.01067-16] [PMID] [PMCID] 
9. Ellafi A, Abdallah FB, Lagha R, Harbi B, Bakhrouf A. Biofilm production, adherence and morphological alterations of Shigella spp. under salt conditions. Ann Microbiol. 2011;61(4):741-7. [DOI:10.1007/s13213-010-0190-5]

10. Kang J, Liu L, Liu Y, Wang X. Ferulic Acid Inactivates Shigella flexneri through Cell Membrane Destruction, Biofilm Retardation, and Altered Gene Expression. J Agric Food Chem. 2020;68(27):7121-31. [DOI:10.1021/acs.jafc.0c01901] [PMID]

11. Yamaguchi $\mathrm{Y}$, Park J-H, Inouye M. Toxin-Antitoxin Systems in Bacteria and Archaea. Annu Rev Genomics. 2011;45(1):61-79.

[DOI:10.1146/annurev-genet-110410-132412] [PMID]

12. Goeders N, Van Melderen L. Toxin-Antitoxin Systems as Multilevel Interaction Systems. Toxins. 2014;6(1):304-24. [DOI:10.3390/toxins6010304] [PMID] [PMCID]

13. Yamaguchi $Y$, Inouye $M$. Chapter 12 mRNA Interferes, Sequence-Specific Endoribonucleases from the Toxin-Antitoxin Systems. Progress in Molecular Biology and Translational Science. 85: Academic Press; 2009. p. 467-500.

[DOI:10.1016/S0079-6603(08)00812-X]

14. Wen Y, Behiels E, Devreese B. Toxin-Antitoxin systems: their role in persistence, biofilm formation, and pathogenicity. Pathog Dis. 2014; 70(3):240-9. [DOI:10.1111/2049-632X.12145] [PMID]

15. Karimi S, Ghafourian S, Taheri Kalani M, Azizi Jalilian F, Hemati S, Sadeghifard N. Association between toxin-antitoxin systems and biofilm formation. Jundishapur J Microbiol. 2014;8(1) :e14540. [DOI:10.5812/jim.14540] [PMID] [PMCID]

16. Christensen SK, Maenhaut-Michel G, Mine N, Gottesman S, Gerdes K, Van Melderen L. Overproduction of the Lon protease triggers inhibition of translation in Escherichia coli: involvement of the yefM-yoeB toxin-antitoxin system. Mol Microbiol. 2004;51(6):1705-17. [DOI:10.1046/j.1365-2958.2003.03941.x] [PMID]

17. Venkatesh S, Lee J, Singh K, Lee I, Suzuki CK. Multitasking in the mitochondrion by the ATPdependent Lon protease. Biochim Biophys Acta Mol Cell Res. 2012;1823(1):56-66. [DOI:10.1016/j.bbamcr.2011.11.003] [PMID] [PMCID]

18. Kheradmand E, Razavi S, Talebi M, Jamshidian M. Evaluation of Putative Type II Toxin-Antitoxin Systems and Lon Protease Expression in Shigella flexneri Following Infection of Caco-2 Cells. Archives of Clinical Infectious Diseases. 2020;15 (3):e98625. [DOl:10.5812/archcid.98625]

19. Hearn RP, Arblaster KE. DNA extraction techniques for use in education. Biochem Mol Biol Educ. 2010;38(3):161-6. [DOI:10.1002/bmb.20351] [PMID]

20. Stepanović S, Vuković D, Hola V, Bonaventura GD, Djukić S, Cirković I, et al. Quantification of biofilm in microtiter plates: overview of testing conditions and practical recommendations for assessment of biofilm production by staphylococci. APMIS. 2007;115(8):891-9. [DOI:10.1111/j.1600-0463.2007.apm 630.x] [PMID]

21. Kubista $M$, Andrade JM, Bengtsson $M$, Forootan A, Jonák J, Lind $\mathrm{K}$, et al. The real-time polymerase chain reaction. Mol Aspects Med. 2006;27(23):95-125. [DOI:10.1016/i.mam.2005.12.007] [PMID]

22. Hemati S, Azizi-Jalilian F, Pakzad I, Taherikalani M, Maleki A, Karimi S, et al. The correlation between the presence of quorum sensing, toxin-antitoxin system genes and MIC values with ability of biofilm formation in clinical isolates of Pseudomonas aeruginosa. Iran J Microbiol. 2014;6(3):133-9.

23. Wood TL, Wood TK. The HigB/HigA toxin/antitoxin system of Pseudomonas aeruginosa influences the virulence factors pyochelin, pyocyanin, and biofilm formation. MicrobiologyOpen. 2016;5(3):499-511. [DOI:10.1002/mbo3.346] [PMID] [PMCID]

24. Valadbeigi $H$, Sadeghifard $N$, Salehi $M B$. Assessment of biofilm formation in Pseudomonas aeruginosa by antisense mazE-PNA. Microb Pathog. 2017;104:28-31.

\section{[DOI:10.1016/i.micpath.2017.01.009] [PMID]}

25. Chan W, Domenech M, Moreno-Córdoba I, Navarro-Martínez V, Nieto C, Moscoso M, et al. The Streptococcus pneumoniae yefM-yoeB and relBE Toxin-Antitoxin Operons Participate in Oxidative Stress and Biofilm Formation. Toxins. 2018;10(9):378. [DOI:10.3390/toxins10090378] [PMID] [PMCID]

26. Alhusseini LB, Maleki A, Kouhsari E, Ghafourian S, Mahmoudi M, Al Marjani MF. Evaluation of type II toxin-antitoxin systems, antibiotic resistance, and biofilm production in clinical MDR Pseudomonas aeruginosa isolates in Iraq. Gene Rep. 2019;17:100546. [DOI:10.1016/i.genrep.2019.100546] 
27. Ma D, Mandell JB, Donegan NP, Cheung AL, Ma $W$, Rothenberger $S$, et al. The Toxin-Antitoxin MazEF Drives Staphylococcus aureus Biofilm Formation, Antibiotic Tolerance, and Chronic Infection. mBio. 2019;10(6):e0165819. [DOI:10.1128/mBio.01658-19]

28. Søgaard-Andersen L, Yang Z. Programmed Cell Death: Role for MazF and MrpC in Myxococcus Multicellular Development. Curr Biol. 2008;18(8):R337-R9.

[DOI:10.1016/i.cub.2008.02.060] [PMID]
29. Kwan BW, Lord DM, Peti W, Page R, Benedik MJ, Wood TK. The MqsR/MqsA toxin/antitoxin system protects Escherichia coli during bile acid stress. Environ Microbiol. 2015;17(9):3168-81. [DOI:10.1111/1462-2920.12749] [PMID]

30.Javanmard Z, Kalani BS, Razavi S, Farahani NN, Mohammadzadeh $R$, Javanmard $F$, et al. Evaluation of cell-penetrating peptide-peptide nucleic acid effect in the inhibition of cagA in Helicobacter pylori. Acta Microbiol Immunol Hung. 2020;67(1):66-72. [DOI:10.1556/030.66.2019.032] [PMID] 


$$
\begin{aligned}
& \text { مجله ميكروبشناسى يزشكى ايران } \\
& \text { سال صا ـ شماره هـ ـ مهر و آبان ••lf } \\
& \text { Journal homepage: www.ijmm.ir }
\end{aligned}
$$

\title{
ارزيابى تشكيل بيوفيلم شيكلا فلكسنرى و تأثير آن بر بيان زنهاى توكسين-آنتىتوكسين
}

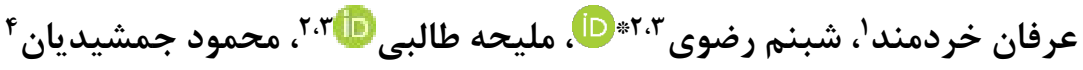

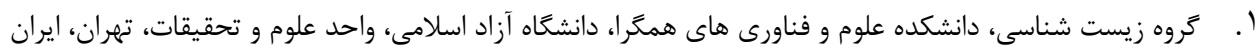

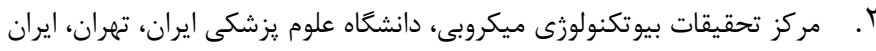

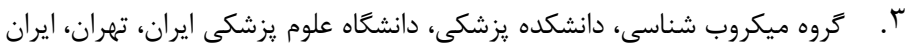

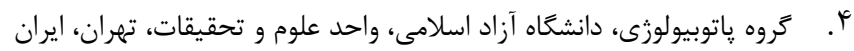

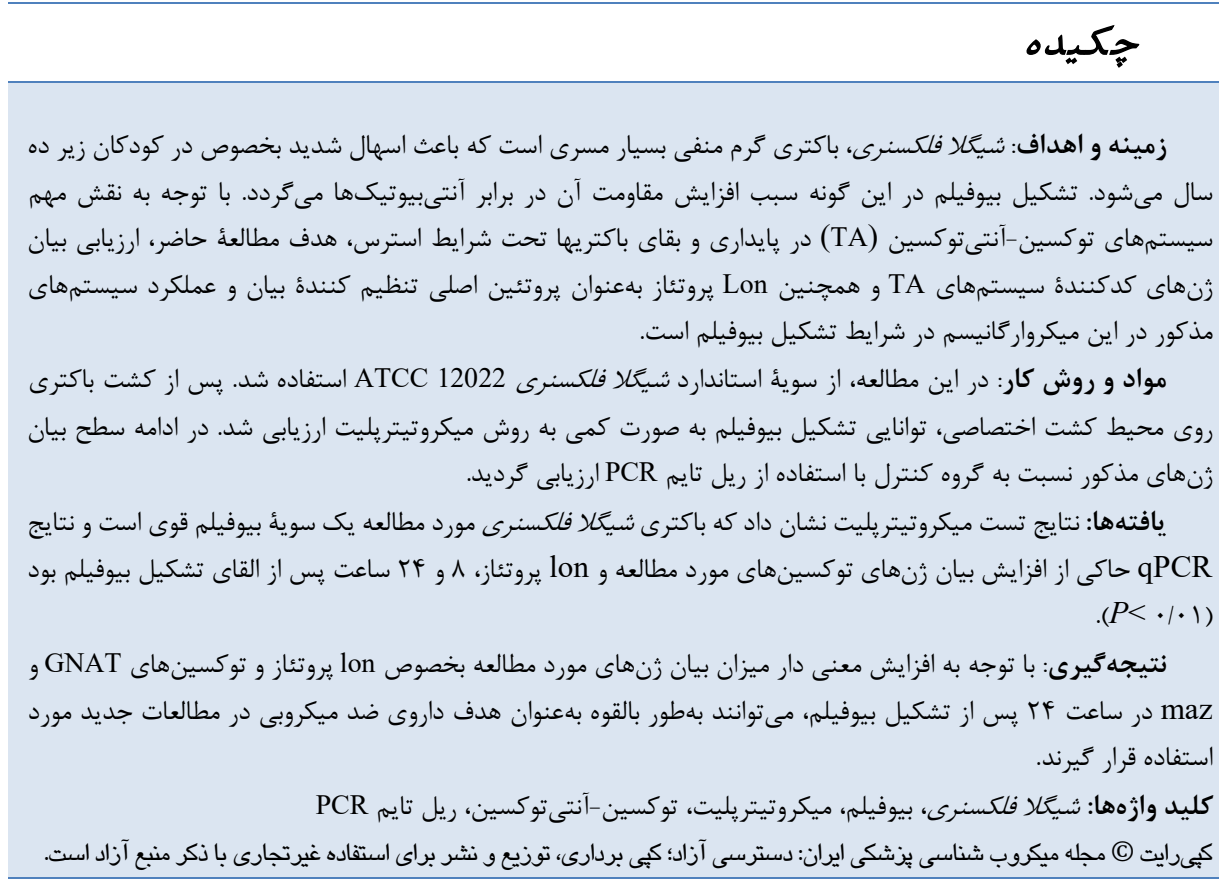

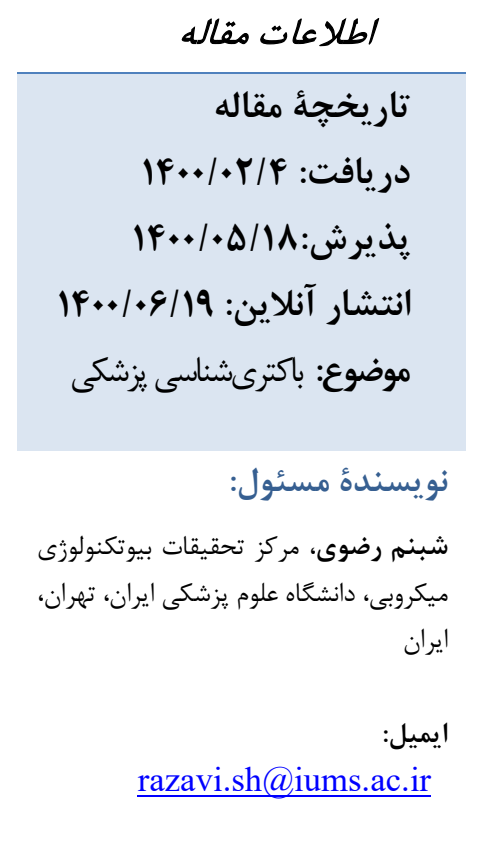

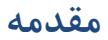

به افزايش مقاومت آنتىبيوتيكى، براى مقابله با عوامل عفونى ابتدا شيكلا فلكسنرى ميكروار كانيسمى با دوز عفونتزايى يايين بايد مطالعات زيادى بر روى بيمارى زايى، راههاى فرار از سيسته

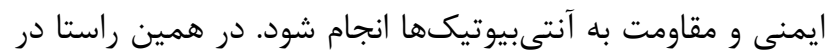

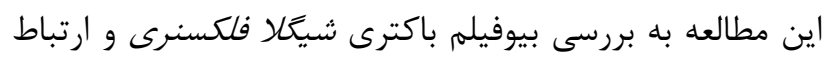

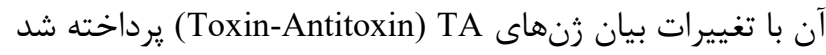

بيوفيلمها تجمعى از كلنىهاى ميكروبى هستند كه سبب

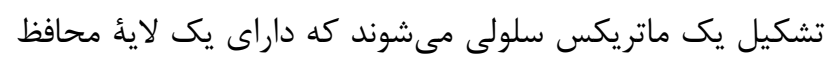
يلى ساكاريدى است و تشكيل بيوفيلم عامل اصلى دخيل در بقاو و

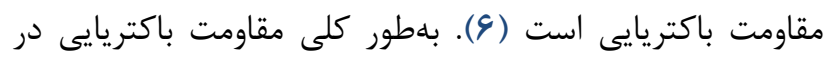

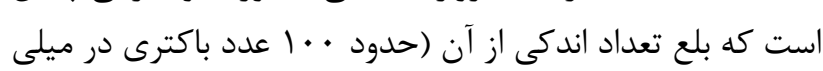

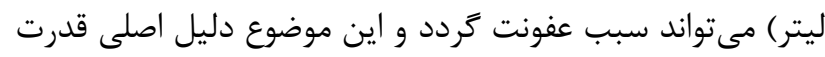

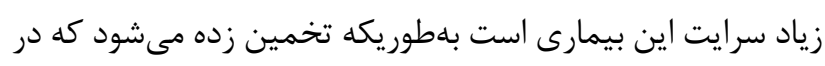

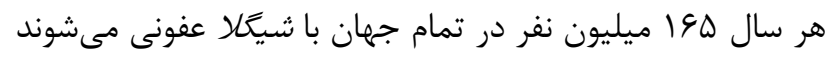
و اين بيمارى، منجر به حدود // / ميليون مرك و مير مى كردد (1,

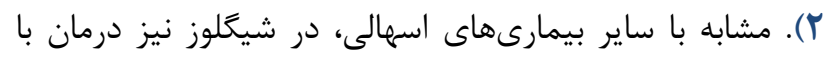

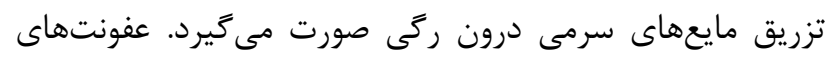

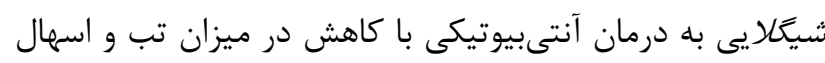

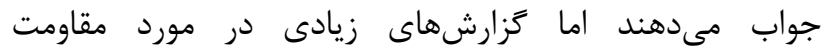

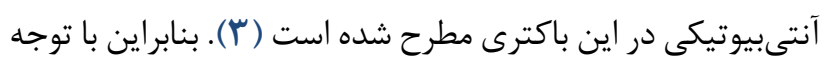


در اين مطالعه بررسى تغييرات بيان زنها با بررسى بيوفيلم باكترى شيعلا فلكسنرى نسبت به كنترل است.

$$
\text { مواد و روشها }
$$

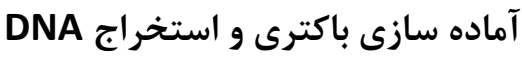

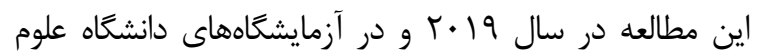

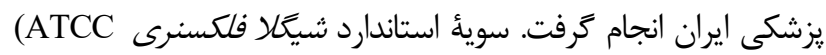

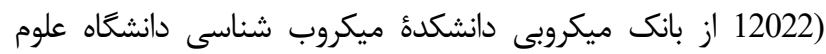

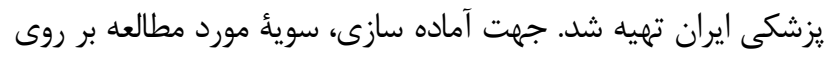

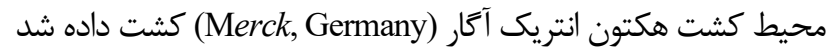

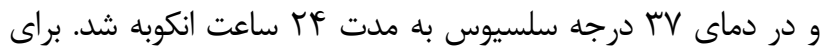

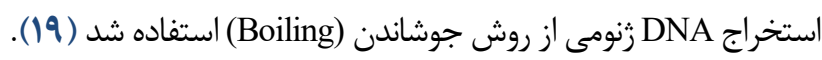
در ادامه كيفيت و غلظت DNA استخراج شده، توسط دستكاه نانودراب مورد ارزيابى (Nanodrop Technologies, Wilmington, De, USA)

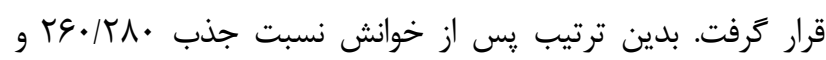

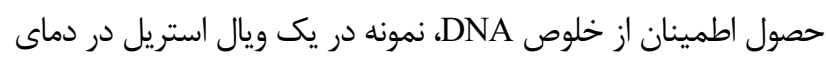

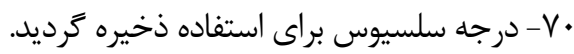

\section{واكنش زنجيره ای يليمراز و الكتروفورز}

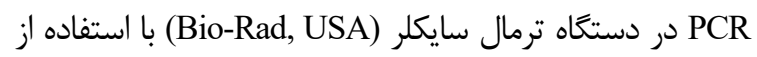

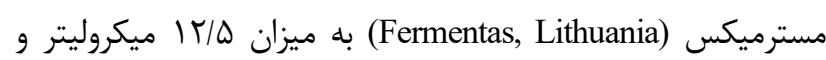
DNA استخراج شده به ميزان ا ميكروليتر انجام كرفت. در اين مطالعه مئه

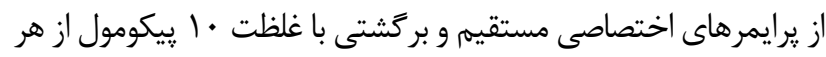

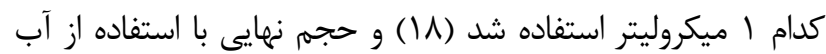

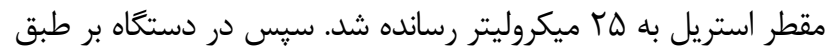

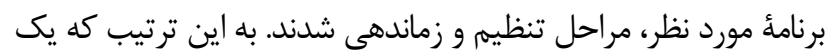

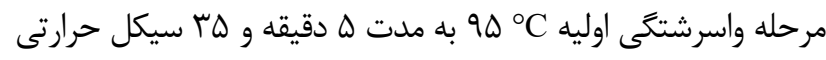

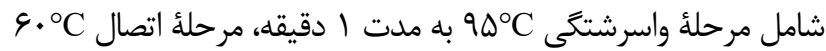

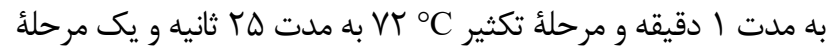

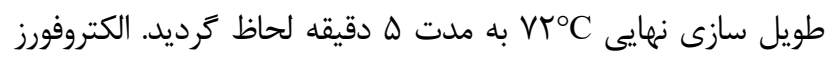

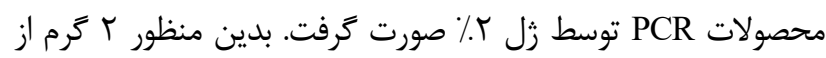

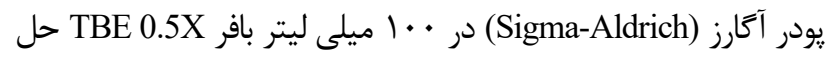

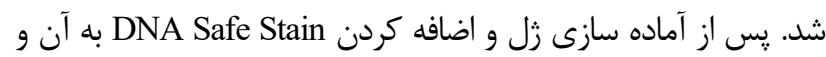

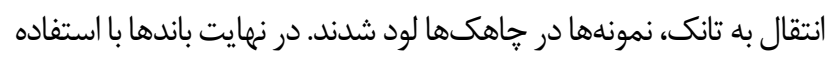
از زل داك بررسى و عكسبردارى شدند.

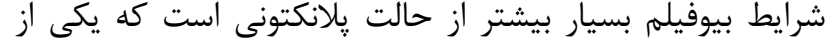

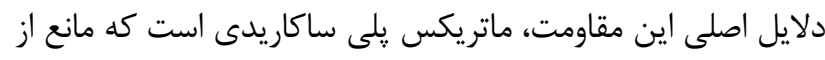

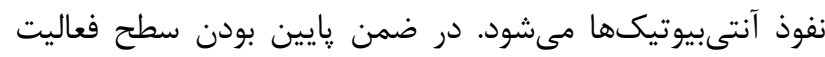

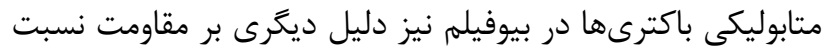

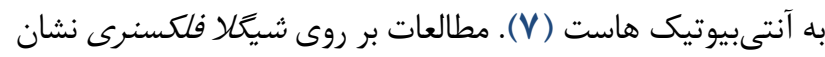

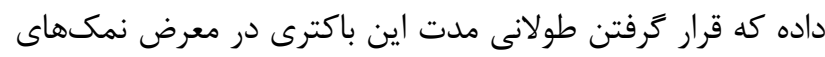

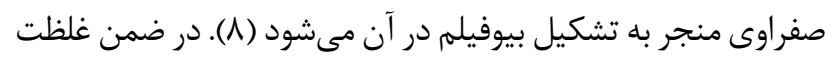

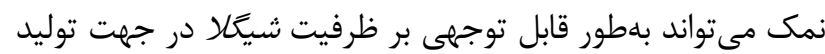

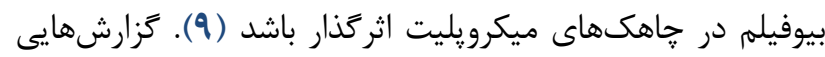
نيز حاكى از آن بود كه فروليك اسيد، تشكيل بيوفيلم توسط شيكايكا

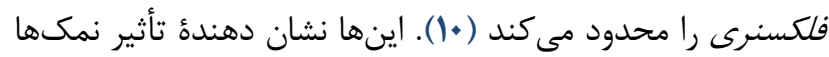
و اسيدهاى مختلف بر تشكيل بيوفيلم اين باكترى است.

از سوى ديخر در مورد سيستمهاى TA مطالعات اخير نشان

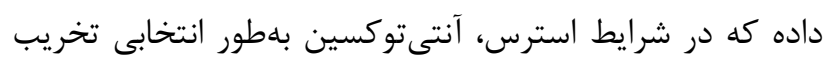

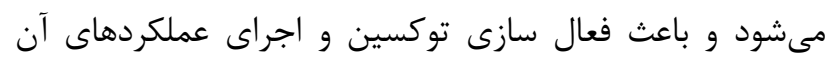

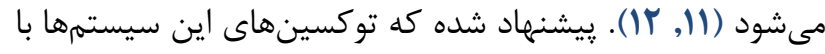

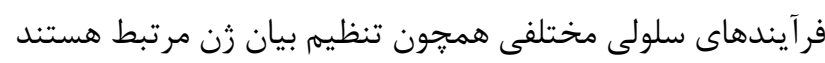

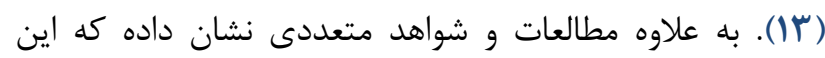

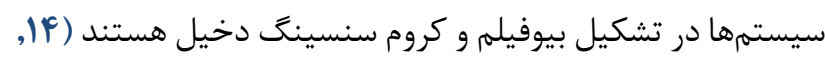

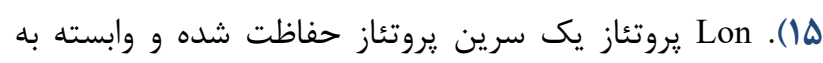

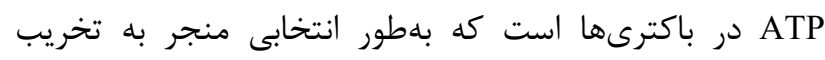
يروتئينهاى جهش يافته و غير طبيعى و همجنين برخى

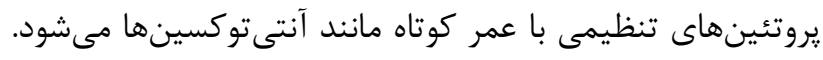

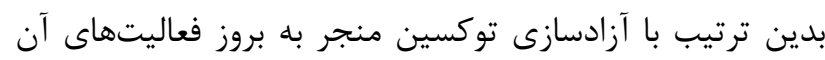

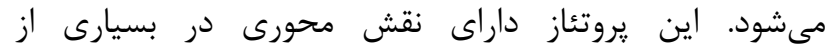

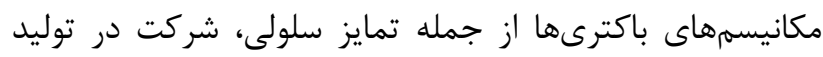
بيوفيلم و بقاى باكترىها است (IV (IV )

از آنجايى كه اطلاعات جندانى در مورد وجود و شيوع اين سيستمها در باكترى شيكلا فلكسنرى وجود نداشت و با توجه به آنهابه

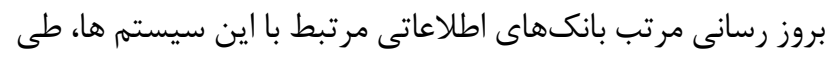

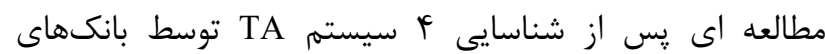

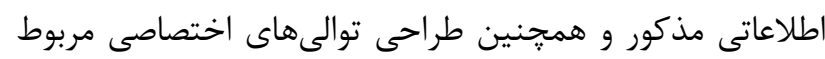

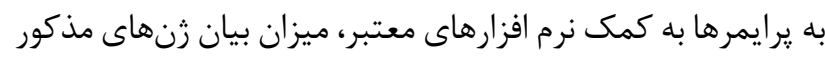

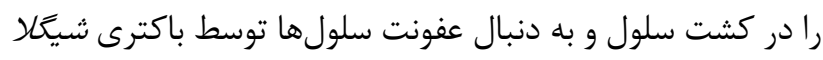

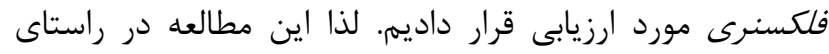

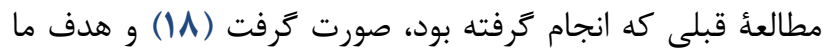


ميكروليتر كلاسيال استيك اسيد سب درصد اضافه شد. بعد از تثبيت

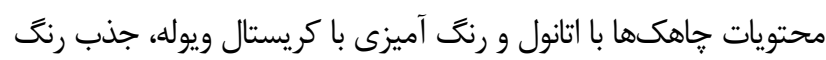

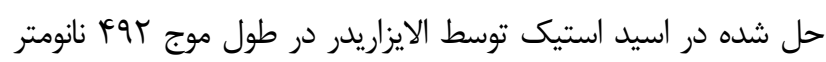

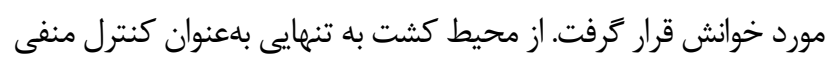

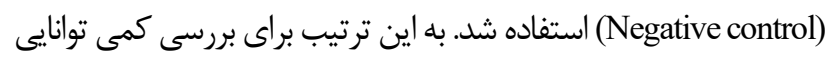

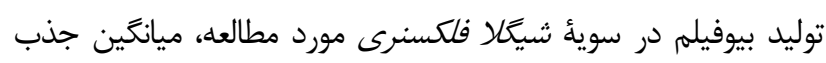

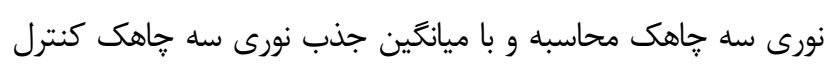
(محيط كشت نشده) مقايسه كرديد و با مقايسٔ اين اعداد توانايى توليد

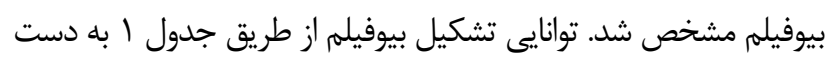

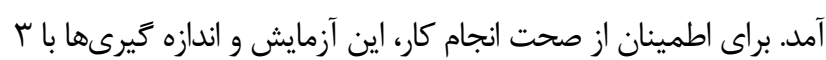

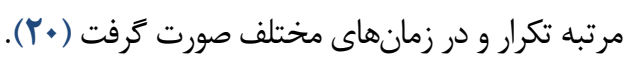

درجه ت موليد بيوفيلم

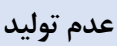

ضعيف

متوسط

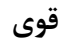

\section{ارزيابى كمى تشكيل بيوفيلم با روش تست ميكروتيتريليت}

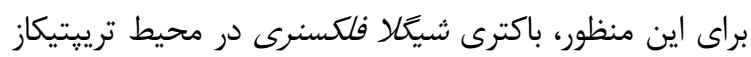

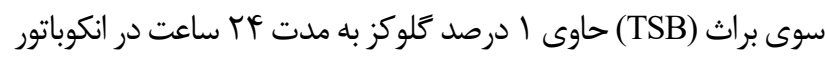

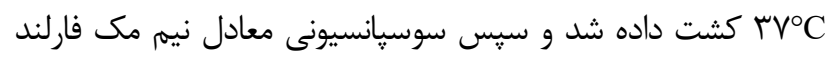

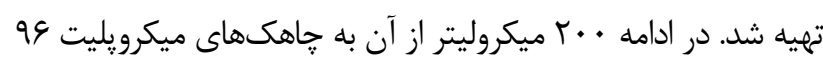

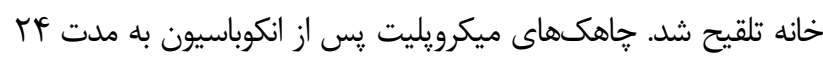
ساعت در PBS

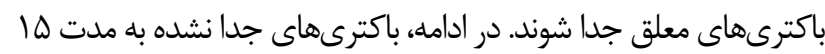

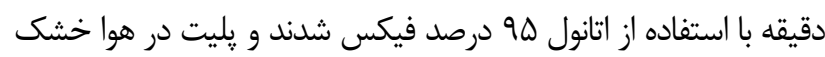

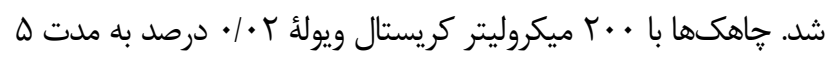

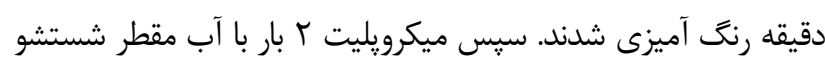

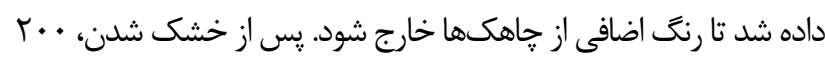

جدول ا. محاسبة ميزان توانايى تشكيل بيوفيلم در مقايسه با كنترل

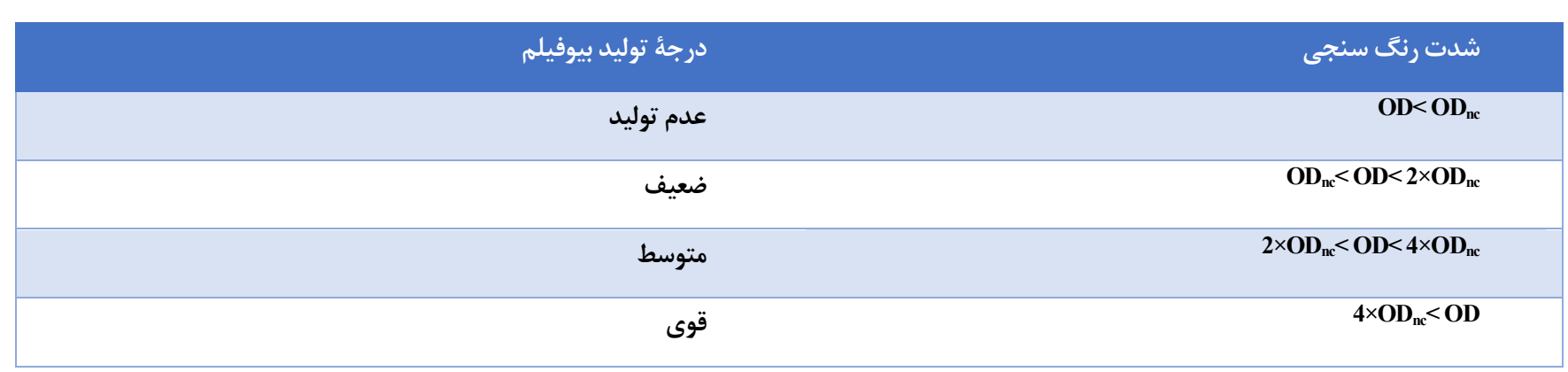

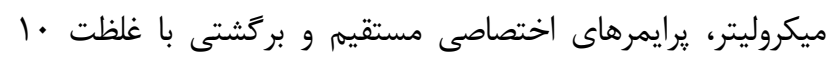

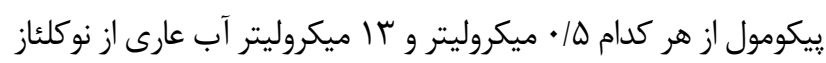

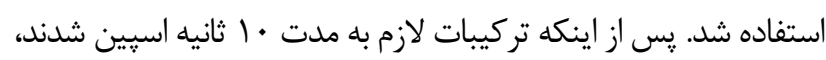

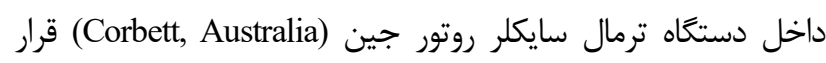

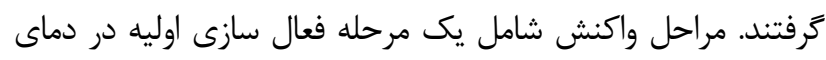
$90^{\circ} \mathrm{C}$

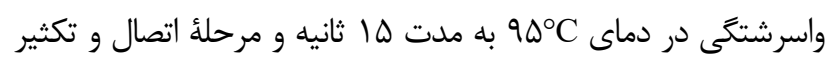

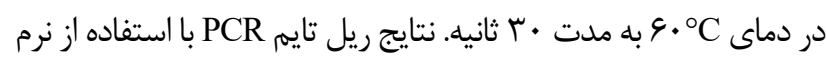

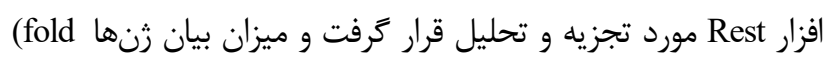

change)

\section{تجزيه و تحليل آمارى}

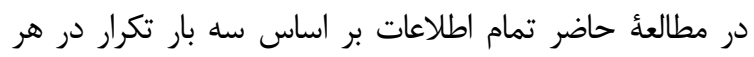

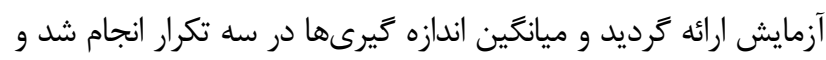

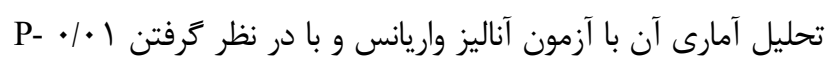

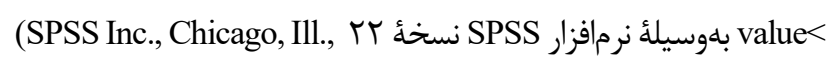
UعA)
بر رسى بيان زنها در شرايط بيوفيلم با استفاده از qPCR

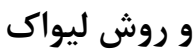

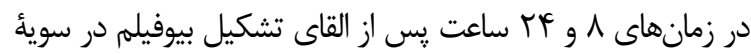

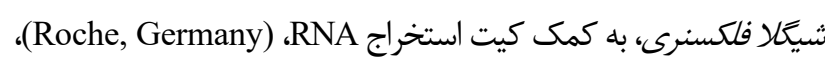

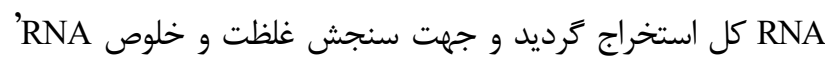

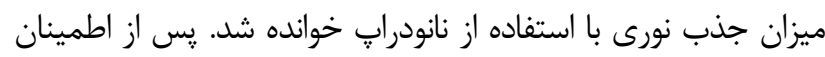

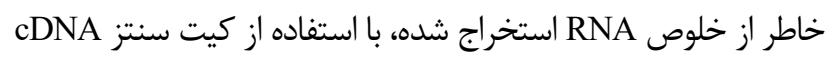
Biotechnology, South Korea) (GeneAll تبديل شد. زن 16S rRNA براى نرمال سازى دادهها مورد استفاده قرار

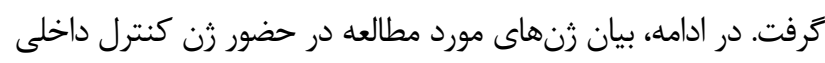

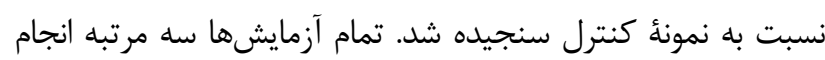

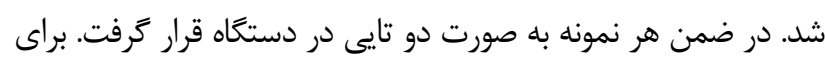

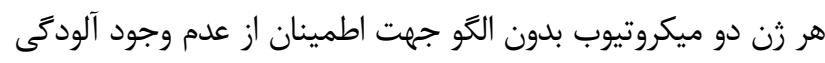

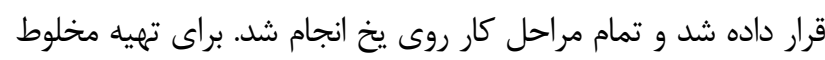

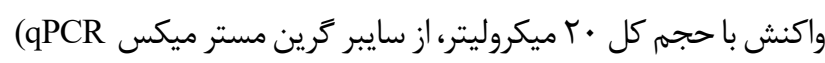

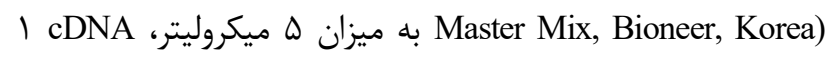


نسبت به كنترل بود. نتايج ميزان بيان رنهاى مورد مطالعه در ساعتهاى

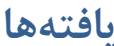

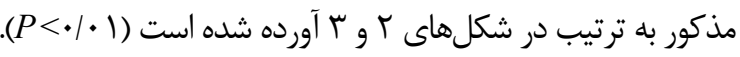

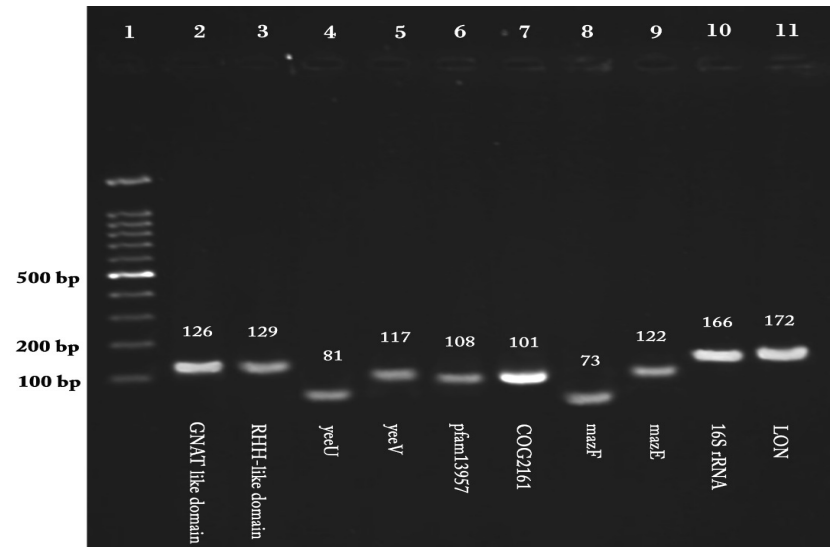

شكل ا. زل نتايج PCR زن هاى مورد مطالعه در سويأ شيعال فلكسنرى
نتيجهُ آزمون واكنش زنجيره ای يليمراز

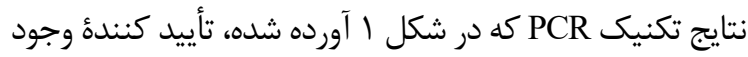

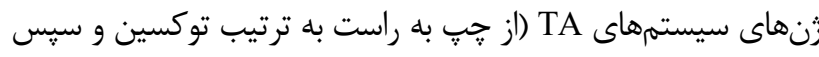

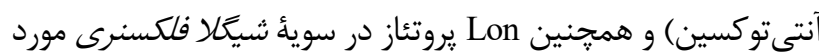
مطالعه بود.

نتايج تشكيل بيوفيلم سوية شيكلا فلكسنرى و ميزان بيان ثنها

توانايى سوية شيكالا فلكسنرى مورد مطالعه در توليد بيوفيلم به روش ميكروتيتريليت و استفاده از الايزا ريدر مورد بررسى قرار كرفت و

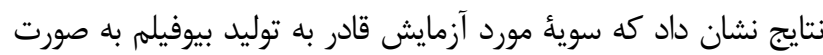

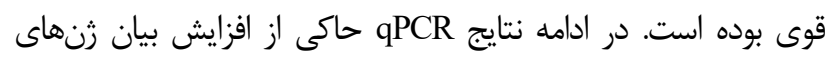

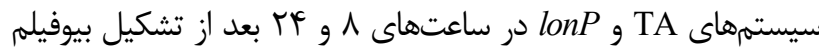

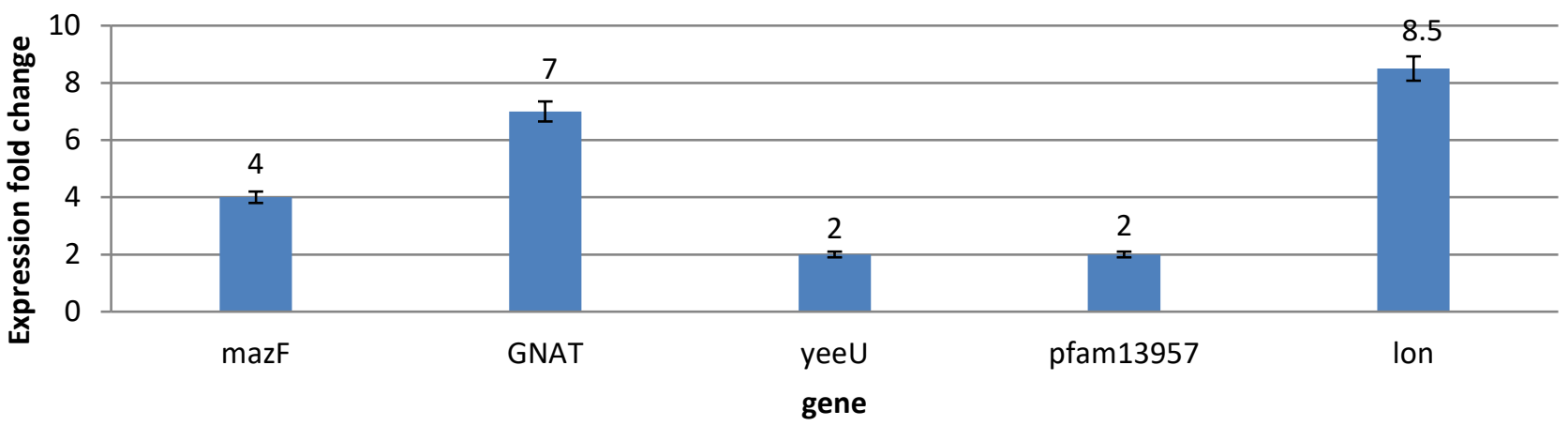

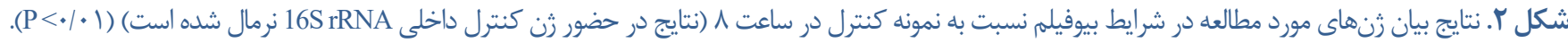

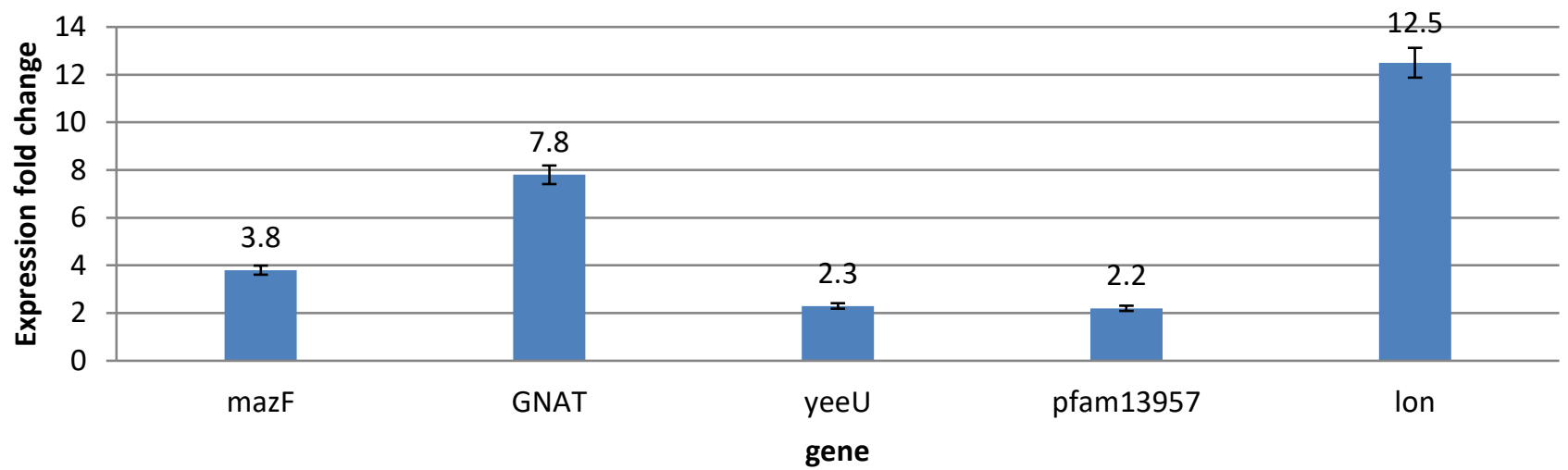

شكل r. نتايج بيان رنهاى مورد مطالعه در شرايط بيوفيلم نسبت به نمونه كنترل در ساعت Y (نتايج در حضور رن كنترل داخلى 16SrRNA نرمال شده است) (1 •>>P). 
همجنين ارتباط ميان اين سيستم و افزايش رشد بيوفيلم نشان

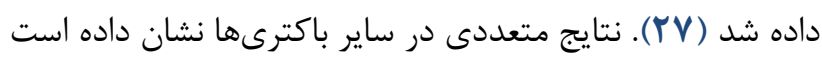
كه توكسين maz در شرايط سخت به بقاى باكترى كمك مى كند دائد

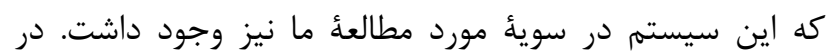

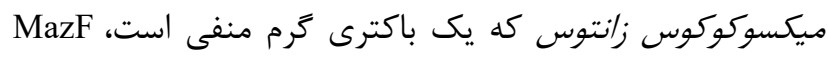
نقش مهمى داشته و با شروع تشكيل جسم توليد كنندة اسيور، القا

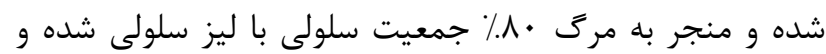

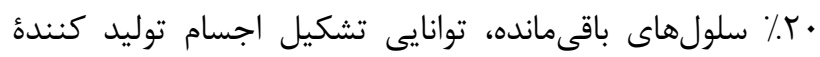

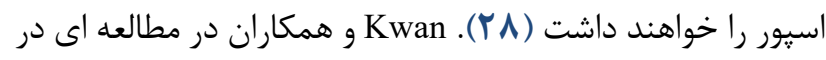

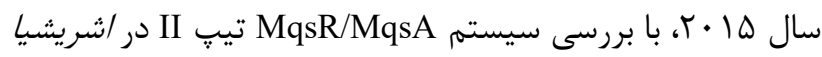
كلى نشان دادند كه با توجه به وجود غلظت بالئ بالى دئوكسيكولات

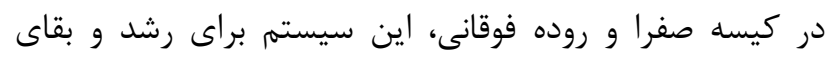
سلولهاى /شريشيا كلى در اين بخشها كه غلظت بالايى از نمك

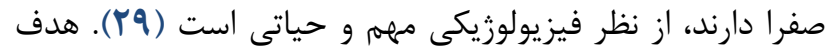
قرار دادن توكسينهاى مههم در اين مطالعه و يروتئاز تنظيم كنندة

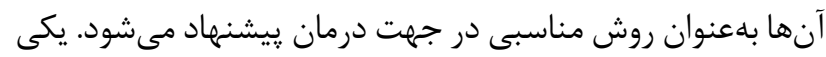

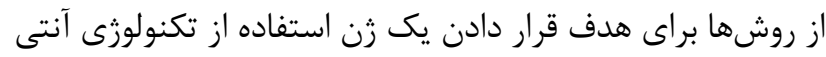

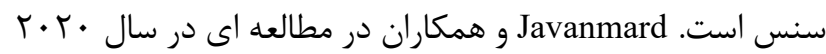

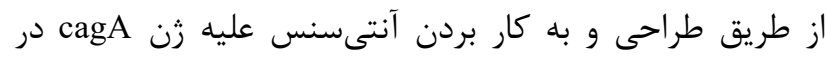

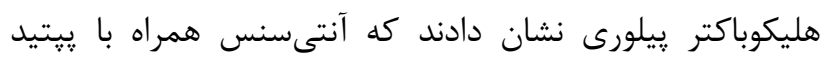
نفوذى مىتواند بهعنوان ابزارى موثر در مهار mRNA زن هدف ادفي

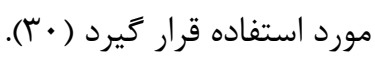

$$
\text { نتيجه تيرى }
$$

در يزوهش حاضر بيان زنها در شرايط بيوفيلم نسبت به

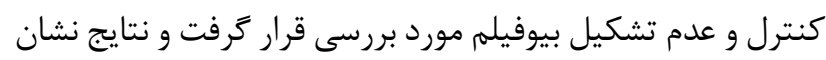
داد كه توكسينهاى GNAT و maz در شرايط بيوفيلم در مقايسه با گروه كنترل افزايش بيان معنى دارى داشتند دائد اين نتايج نشان

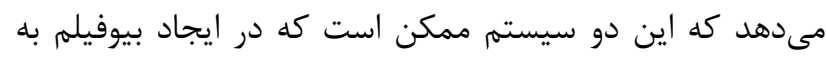
باكترى كمك كنند. در ضمن با توجه به افزايش ميزان بيان زن إن

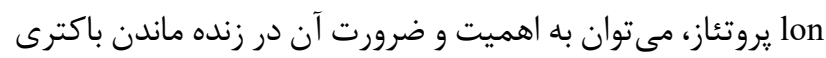

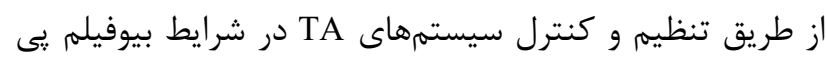

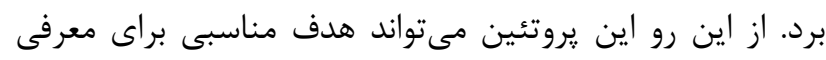
تركيبات جديد درمانى باشد.

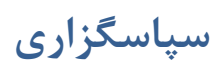

بدينوسيله مراتب تشكر و سياس خود را از تمام افرادى كه در طى انجام اين مطالعه همكارى مؤثر داشتند، اعلام مىنماييم.
با توجه به نتايج به دست آمده در مطالعأ حاضر و افزايش سطح بيان سيستمهاى TA در شرايط تشكيل بيوفيلم، مىتوان به دانه ارتباط ميان سيستمهاى مذكور و تشكيل بيوفيلم بي برد. Hemati

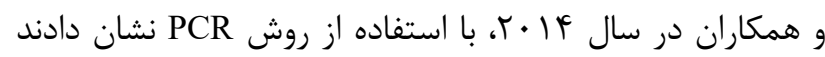

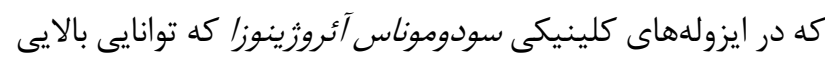

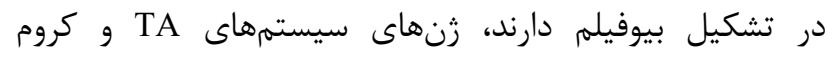

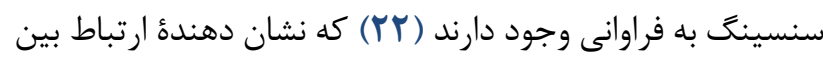

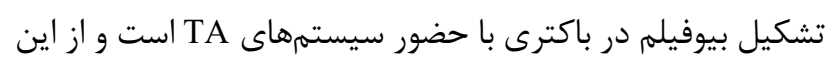

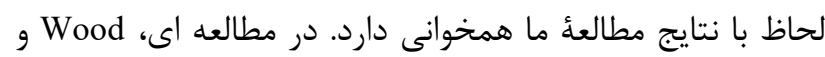

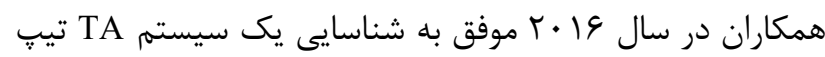

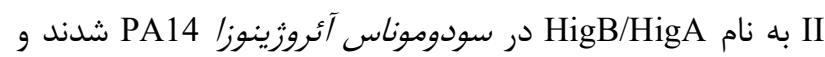
نشان دادند كه توكسين HigB بر ميزان توليد بيوفيلم و فاكتورهاى لترون

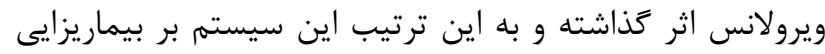

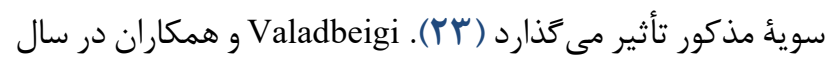

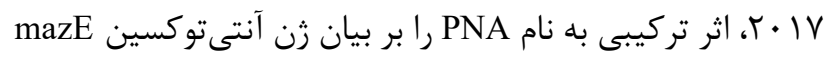

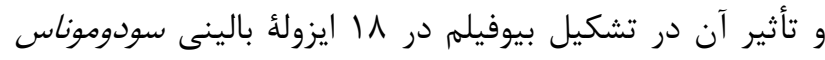

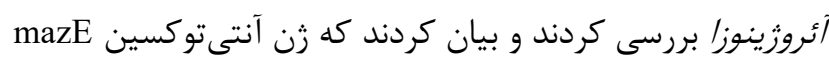

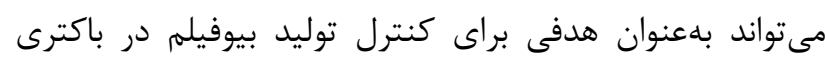

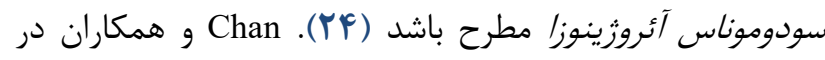

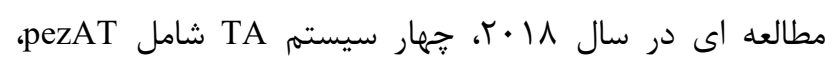
relBE ، yefM-yoeB ينومونيه تشخيص داد و نشان دادند كه سويههاى فاقد سيستم

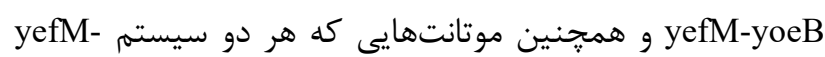

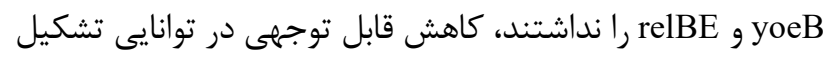

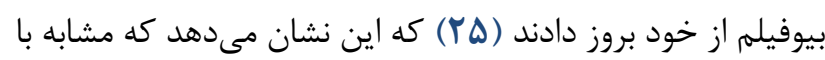

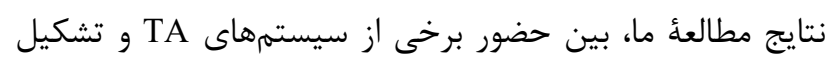

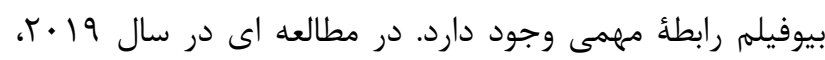
و همكاران با بررسى Alhusseini

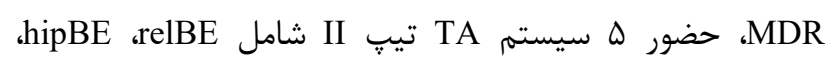

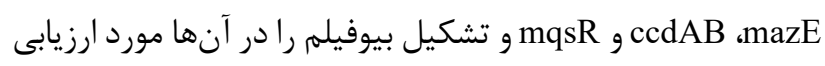

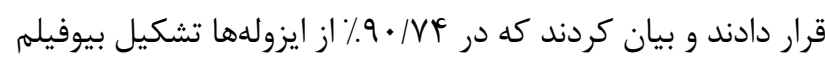

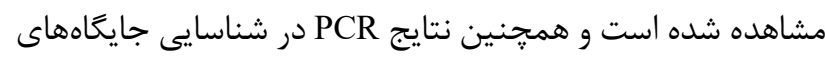
زنهاى سيستمهاى TA نشان داد كه درصد بسيار بالايى از

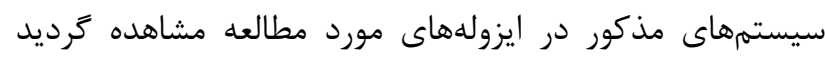
Ma

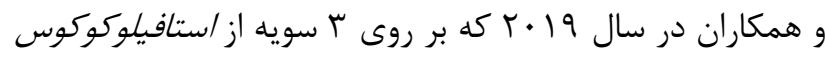

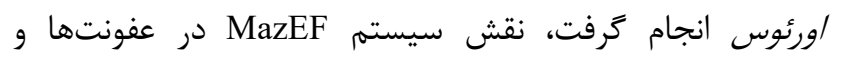




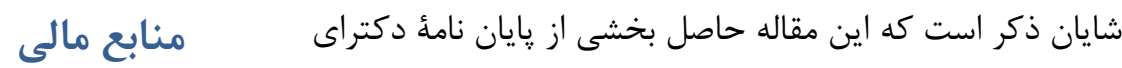

$$
\begin{aligned}
& \text { اين مقاله يزوهشى مستقل است كه بدون حمايت مالى سازمانى } \\
& \text { انجام كرفته است. }
\end{aligned}
$$

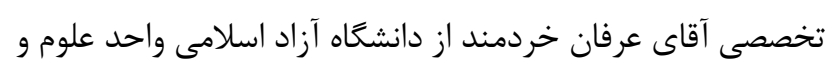

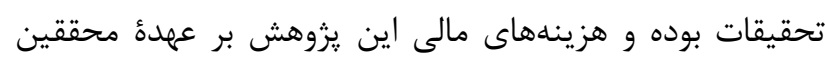

$$
\begin{aligned}
& \text { بوده است. } \\
& \text { تعارض در منافع } \\
& \text { نويسندًان هيج گَونه تعارضى در منافع را زَارش نكردند. }
\end{aligned}
$$

